\title{
Process of Obtaining Sorbents from Bentonite And Refractory Clays Using Industrial Wastes
}

\section{USERBAYEVA B. A., TLEUOVA S.T., TLEUOV A.S., ARYSTANOVA S.D*., BAIYSBAI U.P., KURBANBAYEVA S.N. and BAIYSBAEVA M. P.}

\author{
M. Auezov South Kazakhstan State University, Shymkent, Republic of Kazakhstan. \\ *Corresponding author E-mail: Jasiko2008@mail.ru
}

http://dx.doi.org/10.13005/ojc/350146

Received: October 11, 2018; Accepted: February 08, 2019)

\begin{abstract}
Physico-chemical studies of chemical, mineralogical and phase features of Darbaza clay and swelling agents of oil sludge have been carried out to study the multifunctional sorption properties of local bentonite clays. The contents of the mineralogical and organic part of oil sludge were determined with physicochemical studies. As a result, it was determined that paraffin-naphthenic and aromatic compounds predominate in the organic part and the compounds of silicon, calcium, aluminum and iron predominate in the mineral part. Carried out studies of the modification method of local bentonites with acidic and thermal treatment, which activate sorption properties, are due to the cation exchange of the initial elements of montmorillonite minerals.
\end{abstract}

Keywords: Swelling, Oil sludge, Aluminosilicate sorbents, Thermodynamic modeling, Equilibrium distribution, Kinetic regularities.

\section{INTRODUCTION}

The absorption regions at $350^{\circ} \mathrm{C}, 650^{\circ} \mathrm{C}$, and desorption at $433^{\circ} \mathrm{C}$ are determined with method of thermo programmed reduction and hydrogen desorption. Thermodynamic studies of calculating ${ }^{1,2}$ Gibbs energy of possible synthesis conversion of sorbent minerals with the addition of oil sludge have established that the greatest thermodynamic probability is characterized by the synthesis of minerals in the presence of $\mathrm{C}_{6} \mathrm{H}_{6}$, and the lowest is in the presence of methane.

Hydrocarbons according to the calculation of Gibbs energy form a series: $\mathrm{CH}_{4}>\mathrm{C}_{6} \mathrm{H}_{6} \mathrm{O}>\mathrm{C}_{6} \mathrm{H}_{6}$. In the presence of $\mathrm{C}_{6} \mathrm{H}_{6}$, the synthesis probability increases in the following series of minerals: $\mathrm{Al}_{2} \mathrm{O}_{3} \cdot \mathrm{SiO}_{2}>\mathrm{CaO} \cdot \mathrm{SiO}_{2}>3 \mathrm{Al}_{2} \mathrm{O}_{3} \cdot 2 \mathrm{SiO}_{2}>\mathrm{Na}_{2} \mathrm{O} \cdot \mathrm{CaO}$ ${ }_{2} \mathrm{SiO}_{2}>\mathrm{CaO} \cdot \mathrm{Al}_{2} \mathrm{O}_{3} \cdot 2 \mathrm{SiO} \mathrm{O}_{2}>\mathrm{CaO} \cdot \mathrm{MgO} \cdot 2 \mathrm{SiO}_{2}$. The physical and mechanical properties of activated bentonite clays with the addition of oil sludge 10-30\% are much higher than those of the refractory clays of the Lenger deposit ${ }^{3-5}$.

The formation process of the porous structure of sorbents, as well as their swelling is affected by the chemical, mineralogical and granulometric compositions of refractory clay rocks.

This is an Open Access article licensed under a Creative Commons license: Attribution 4.0 International (CC- BY). Published by Oriental Scientific Publishing Company @ 2018

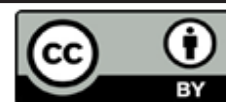


Research of the materials porosity by swelling, the softened mass from within the gaseous phase contained in the charge or artificially introduced into is of particular importance in the development of the theoretical foundations of an effective technology for the sorbents production.

The pores of the swollen samples $\mathrm{CO}_{2}, \mathrm{H}_{2} \mathrm{O}$, $\mathrm{O}_{2}, \mathrm{SO}_{2}, \mathrm{~N}_{2}, \mathrm{CO}, \mathrm{H}_{2}, \mathrm{CH}_{4}$ were found in the gas phase in the researches of A. Zhukov, V. Sisktor ${ }^{6,7}$. In the opinion of these authors, the formation of gaseous compounds is due to the dissociation of carbonates, the reduction of iron oxides, the decomposition of sulfates, water, minerals and impurities. Moreover, the quantitative indicators on the formation of gas phase components are widely spread and give evidence of the need for continuing research in this field. In this connection, the characteristic reactions of aluminosilicate compounds formation in the presence of hydrocarbon components corresponding to oil sludge were considered to determine the composition of the gas phase, the quantitative distribution of elements ${ }^{8-10}$.

The determination of formation conditions of aluminosilicate minerals, sorbents, using as the main clay component of Darbaza bentonite clays and refractory clays of the Lenger deposit represents interest with reference to the being developed technology. Darbaza clay belongs to the first group and is a good swelling material, which makes it possible to obtain sorbent samples with an apparent density in the piece in the range $0.2-0.5 \mathrm{~g} / \mathrm{cm}^{3}$ with a swelling coefficient of more than 3-4.5. Lenger clay belongs to the third group and is a clayed weaklyswelling raw material, on the basis of which it is possible to obtain a sorbent with an apparent density of 0.8-1.2 $\mathrm{g} / \mathrm{cm}^{3}$ and swelling ratio below 2.5-2. (Table 1)

Table 1: Chemical composition of clays, (wt.\%)

\begin{tabular}{lcccccccccc}
\hline Sample name & $\mathrm{SiO}_{2}$ & $\mathrm{Al}_{2} \mathrm{O}_{3}$ & $\mathrm{Fe}_{2} \mathrm{O}_{3}$ & $\mathrm{TiO}_{2}$ & $\mathrm{CaO}$ & $\mathrm{MgO}$ & $\mathrm{S}$ & $\mathrm{Na}_{2} \mathrm{O}$ & $\mathrm{K}_{2} \mathrm{O}$ & p.p.p. \\
\hline Lenger clay & 59,86 & 20,46 & 6,15 & 0,75 & 1,32 & 1,41 & 0,14 & 0,26 & 2,8 & 6,8 \\
Darbaza clay & 59,0 & 17,29 & 7,76 & 0,75 & 1,19 & 3,0 & 1,85 & - & - & 9,1 \\
\hline
\end{tabular}

The phase spectrometric and thermographic characteristics of the initial clay components and swelling additive-oil sludge were determined with physico-chemical methods of analysis.

X-ray phase analysis of the Lenger and Darbaza clays showed that the main characteristic phases of clays are calcium feldspars with $d=4.21$, $4.17 \AA$ and potassium feldspars with $d=4.31$; 3.31 ; $3.08 ; 2.99 ; 2.97 \AA$. The montmorillonite phase is characterized by diffraction maxima with $d=4.31$; $3.92 ; 2.56 ; 2.22 \AA$. The diffraction lines with $d=4.37$; $4.31 ; 2.45 ; 2.38 \AA$ (Fig. 1 ) are characteristic to the compound $\mathrm{Al}_{2} \mathrm{O}_{3} \cdot 3 \mathrm{H}_{2} \mathrm{O}$.

Production activities of oil refineries inevitably have technogenic impact on the natural environment. The most dangerous pollutant of all components of the natural environment; surface and groundwater, soil and vegetation cover, atmospheric air is oil-containing waste - oil sludge. Oil sludge in oil refineries is formed in the process of oil refining and wastewater treatment, they are a mixture of precipitations and emulsions detained in sewage treatment plants-sandpipers, oil traps, radial sedimentation tanks, floaters and secondary radial sedimentation tanks. On the toxicity oil sludge is industrial wastes of the third class.

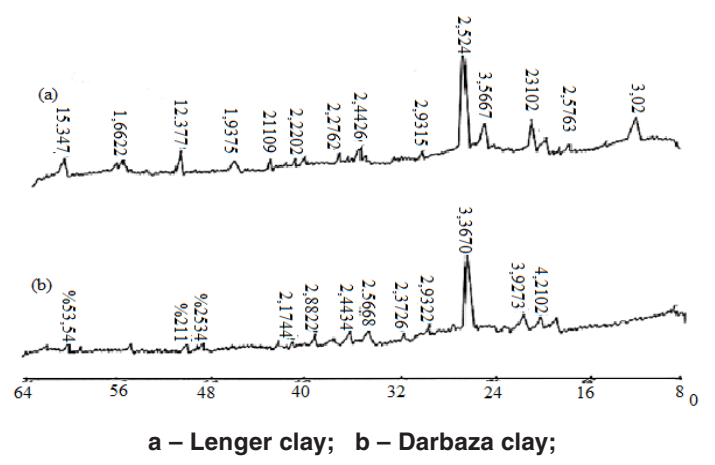

Fig. 1. Radiogram of clays

The main quantity of sludge is accounted for by floaters (35-45\%) and oil trap (25-30\%). Sludge is heavy oil residues, containing on the average (on weight) $56-75 \%$ of oil products, $30-85 \%$ of water, $1.3-46 \%$ of solid impurities, their yield is approximately $0.007 \mathrm{~g}$. per 1 ton of processed oil.

The main components of oil sludge are oil, oil products contaminated with chemicals, 
mineralized water and solid suspended substances of various origins. Analysis of the submitted oil sludge sample showed that the content of petroleum products in the upper layers of oil sludge is approximately the same, except for the surface layer enriched with floating oil, an average of $8.1 \%$. The reserves of oil products in all sludge accumulators are about 200-300 tons. The content of mineral impurities in the lower layers is higher than in the upper layers and on average $25-40 \%$. The mineral impurities included in the oil sludge consist mainly of hard sandy and argillaceous particles, industrial dust, coke and coal smut, corrosion products, metal hydroxide particles, alkaline earth metal carbonates, iron carbonates and sulfides, elemental sulfur, and biogrowth of the circulating water

supply system. On the basis of mass spectrometric analysis it was established that paraffin-naphthenic, aromatic and resinous components predominate in the hydrocarbon part, with asphaltene inclusions (Table 2).

Table 2: Oil sludge content in the sludge collector

\begin{tabular}{|c|c|c|c|c|}
\hline \multirow[b]{2}{*}{ Layer } & \multirow[b]{2}{*}{ Collector } & \multicolumn{3}{|c|}{ Composition, \% } \\
\hline & & oil products & mineral impurities & water \\
\hline Upper & & 18,8 & 2,2 & 89,0 \\
\hline Average & No 1 & 24,4 & 4,8 & 70,8 \\
\hline Lower & & 16,5 & 40,5 & 43,0 \\
\hline Upper & & 6,7 & 3,3 & 90 \\
\hline Average & No 3 & 25,7 & 11,3 & 60 \\
\hline Lower & & 16,8 & 41,4 & 42,8 \\
\hline Upper & & 8,8 & 4,0 & 82,2 \\
\hline Average & No 4 & 26,2 & 8,9 & 64,9 \\
\hline Lower & & 18,0 & 40,3 & 41,7 \\
\hline
\end{tabular}

Table 3: Chemical composition of oil sludge

\begin{tabular}{lcccccccc}
\hline Title & \multicolumn{6}{c}{ Chemical composition, mass \% } \\
& $\begin{array}{c}\text { oil } \\
\text { products }\end{array}$ & part & ness & $\mathrm{SiO}_{2}$ & $\mathrm{CaO}$ & $\mathrm{Fe}_{2} \mathrm{O}_{3}$ & $\mathrm{Al}_{2} \mathrm{O}_{3}$ & p.p.p. \\
\hline $\begin{array}{l}\text { Oil } \\
\text { sludge }\end{array}$ & $70-75$ & $15-20$ & $12-20$ & 24,8 & 17,3 & 9,47 & 10,9 & rest \\
\hline
\end{tabular}

Table 4: Hydrocarbon composition of denuded oil part of oil sludge

\begin{tabular}{cc}
\hline Name of components & Content, \% mass \\
\hline Paraffin-naphthene & 36 \\
Hydro carbons & 22,5 \\
Aromatic & 18,1 \\
Resin & 8,2 \\
Asphaltenes & 0,4 \\
Ash-content & 0,8 \\
Sulfur & 4,0 \\
Cokeability & \\
\hline
\end{tabular}

Differential-thermal analysis of samples of oil sludge was carried out on the derivatograph of the Paulik-Erdei system under the following conditions: heating rate $50 \mathrm{deg} / \mathrm{min}$; basic reference standard- calcined alumina (III); crucibles corundum, temperature range 293-1273K; the sample is $426 \mathrm{mg}$. At surveying the sample of oil sludge in the range up to $358 \mathrm{~K}$, a weakly expressed end effect with a minimum at $328 \mathrm{~K}$ is observed, caused with the weight loss-1.2\%. The further increase in temperature is accompanied by the endo-effect in the range 358$443 \mathrm{~K}$ with a minimum at $383 \mathrm{~K}$, caused with moisture evaporation. The mass loss in the interval $358-443 \mathrm{~K}$ is $38.6 \%$. At $\mathrm{T}>443 \kappa$, the DTA curve is the resultant superposition of exo- and endo effects.

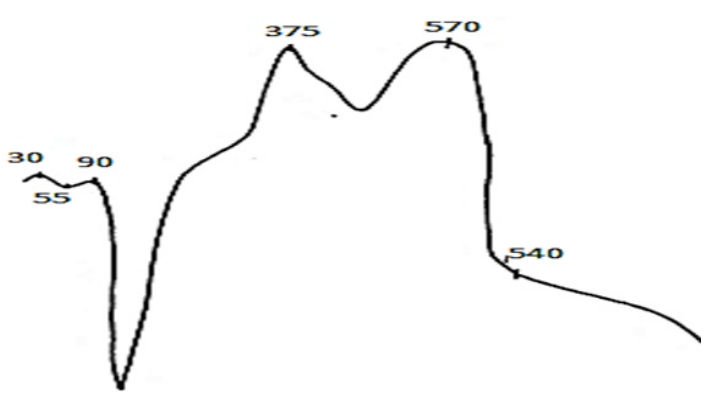

Fig. 2. Thermogram of oil sludge

IR spectrometric analysis of oil sludge (Fig. 2) showed that the height of the infrared absorption bands in the region of $600-900 \mathrm{~cm}^{-1}$ explains the existence of bands characteristic of Si-O-Si valence states, which solely explains the spectral structure of layered silicates in this region. Absorption spectra $1380-1470 \mathrm{~cm}^{-1}$ explains the existence of spectra, characteristic for orthoclase, feldspars, which overlap the spectral region up to $1400-1600 \mathrm{~cm}^{-1}$, as well as spectra characteristic of anorthite, albite, iron-containing microcrystalline. Absorption spectra $12-720 \mathrm{~cm}^{-1}$ explain the existence of minerals of dolomitized calcite.

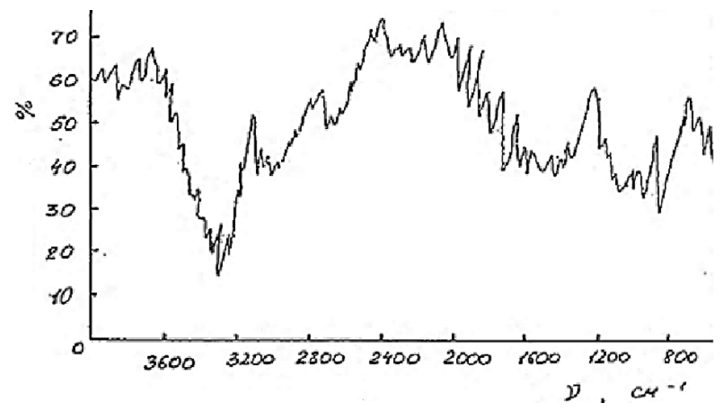

Fig. 3. IR spectrometers of oil sludge 
The samples of oil sludge were placed into the box, they were washed with a gas mixture of $\mathrm{H}_{2}$ and $\mathrm{Ar}(8 \%)$ to determine the zero line of the chromatograph catharometer "Cromadam» to study the thermo programmed reduction and desorption of hydrogen. The gas flow rate is $0.8 \mathrm{ml} / \mathrm{s}$. Then the temperature was linearly heated. The rate of temperature rise was $10^{\circ} \mathrm{C} / \mathrm{min}$ (Figure 3).

Samples of oil sludge samples were heated to $650^{\circ} \mathrm{C}$ and kept at this temperature until the zero line was established for 65-70 minutes. After with standing the samples in the box were cooled to the room temperature in a stream of gas mixture of $\mathrm{H}_{2}$ and Ar. Then the gas mixture was switched to an argon stream at a rate of $0.8 \mathrm{ml} / \mathrm{s}$ and thermal desorption of adsorbed hydrogen was carried out at a temperature rise rate of $100 / \min$ to $650^{\circ} \mathrm{C}$.

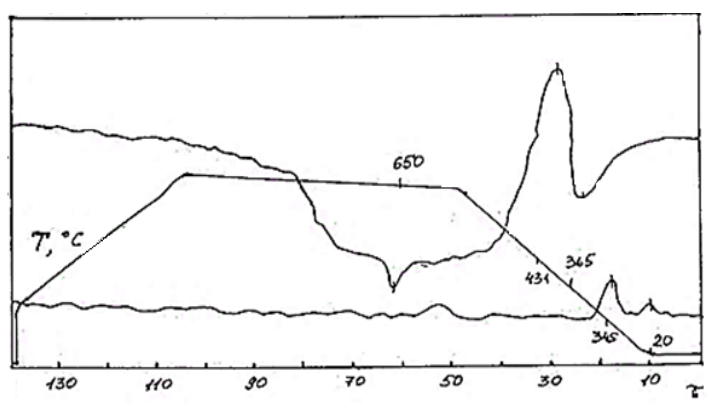

Fig. 4. Thermo programmed recovery and hydrogen desorption

The results of the thermo-programmed reduction (TPR) of hydrogen of the first sample are characterized by the absorption of $\mathrm{H}_{2}$ at $350^{\circ} \mathrm{C}$, then by the isolation, i.e. $\mathrm{H}_{2}$ desorption at $433^{\circ} \mathrm{C}$ and absorption of a large amount of hydrogen at $650^{\circ} \mathrm{C}$. TPR hydrogen desorption from the second sample of oil sludge is characterized by two peaks with Tmax $=200$, at a rate of $0.4 \mathrm{ml} \mathrm{H}_{2} / \mathrm{g}$ and $\mathrm{T}_{\max }=3450$ and at a rate of $0.9 \mathrm{ml} \mathrm{H}_{2} / \mathrm{g}$.

The developed technology for the preparation of sorbents involves using of oil sludge to produce a porous and mechanically strong sorbent.

Thermodynamic studies of the possible formation of minerals of aluminosilicate sorbents in the presence of organic compounds characteristic for the composition of the organic part of oil sludge were carried out using the software complex
"Astra". Thermodynamic modeling is based on the fundamental principle of maximum entropy. The temperature effect on the thermodynamic probability of sorbent minerals formation with using oil sludge was studied for 18 reactions in the interval 298 - $1500 \mathrm{~K}$ :

$\mathrm{SiO}_{2}+\mathrm{CaO}+\mathrm{CH}_{4}+2 \mathrm{O}_{2}=\mathrm{CaO} \cdot \mathrm{SiO}_{2}+\mathrm{CO}_{2}+$
$2 \mathrm{H}_{2} \mathrm{O}$
$\mathrm{SiO}_{2}+\mathrm{CaO}+\mathrm{C}_{6} \mathrm{H}_{6}+7.5 \mathrm{O}_{2}=\mathrm{CaO} \cdot \mathrm{SiO}_{2}+6 \mathrm{CO}_{2}+$
$3 \mathrm{H}_{2} \mathrm{O}$
$\mathrm{SiO}_{2}+\mathrm{CaO}+2 \mathrm{CH}_{3} \mathrm{Cl}+3.5 \mathrm{O}_{2}=\mathrm{CaO} \cdot \mathrm{SiO}_{2}+2 \mathrm{CO}_{2}$
$+3 \mathrm{H}_{2} \mathrm{O}+\mathrm{Cl}_{2}$ $\mathrm{SiO}_{2}+\mathrm{CaO}+\mathrm{C}_{6} \mathrm{H}_{6} \mathrm{O}+7 \mathrm{O}_{2}=\mathrm{CaO} \cdot \mathrm{SiO}_{2}+6 \mathrm{CO}_{2}+$ $3 \mathrm{H}_{2} \mathrm{O}$

$\mathrm{SiO}_{2}+\mathrm{CaO}+\mathrm{C}_{2} \mathrm{H}_{6}+3.5 \mathrm{O}_{2}=\mathrm{CaO} \cdot \mathrm{SiO}_{2}+2 \mathrm{CO}_{2}+$ $3 \mathrm{H}_{2} \mathrm{O}$

$\mathrm{SiO}_{2}+\mathrm{CaO}+\mathrm{C}_{2} \mathrm{H}_{2}+2.5 \mathrm{O}_{2}=\mathrm{CaO} \cdot \mathrm{SiO}_{2}+2 \mathrm{CO}_{2}+$

$\mathrm{H} 2 \mathrm{O}$

$\mathrm{CaO}+\mathrm{Al}_{2} \mathrm{O}_{3}+2 \mathrm{SiO}_{2}+\mathrm{C}_{6} \mathrm{H}_{6}+7.5 \mathrm{O}_{2}=\mathrm{CaO} \cdot \mathrm{Al}_{2} \mathrm{O}_{3}$.

$2 \mathrm{SiO}_{2}+6 \mathrm{CO}_{2}+3 \mathrm{H}_{2} \mathrm{O}$

$\mathrm{CaO}+\mathrm{Al}_{2} \mathrm{O}_{3}+2 \mathrm{SiO}_{2}+\mathrm{C}_{2} \mathrm{H}_{2}+2,5 \mathrm{O}_{2}=\mathrm{CaO} \cdot \mathrm{Al}_{2} \mathrm{O}_{3}$.

$2 \mathrm{SiO}_{2}+3 \mathrm{CO}_{2}+\mathrm{H}_{2} \mathrm{O}$

$\mathrm{CaO}+\mathrm{Al}_{2} \mathrm{O}_{3}+2 \mathrm{SiO}_{2}+\mathrm{C}_{2} \mathrm{H}_{6}+3,5 \mathrm{O}_{2}=\mathrm{CaO} \cdot \mathrm{Al}_{2} \mathrm{O}_{3}$.

$2 \mathrm{SiO}_{2}+2 \mathrm{CO}_{2}+3 \mathrm{H}_{2} \mathrm{O}$

$\mathrm{CaO}+\mathrm{Al}_{2} \mathrm{O}_{3}+2 \mathrm{SiO}_{2}+\mathrm{CH}_{4}+2 \mathrm{O}_{2}=\mathrm{CaO} \cdot \mathrm{Al}_{2} \mathrm{O}_{3} \cdot 2 \mathrm{SiO}_{2}$

$+\mathrm{CO}_{2}+2 \mathrm{H}_{2} \mathrm{O}$

$\mathrm{CaO}+\mathrm{Al}_{2} \mathrm{O}_{3}+2 \mathrm{SiO}_{2}+2 \mathrm{CH}_{3} \mathrm{Cl}+3.5 \mathrm{O}_{2}=\mathrm{CaO} \cdot \mathrm{Al}_{2} \mathrm{O}_{3} \cdot 2 \mathrm{SiO}_{2}$

$+2 \mathrm{CO}_{2}++3 \mathrm{H}_{2} \mathrm{O}+\mathrm{Cl}_{2}$

$\mathrm{CaO}+\mathrm{Al}_{2} \mathrm{O}_{3}+2 \mathrm{SiO}_{2}+\mathrm{C}_{6} \mathrm{H}_{6} \mathrm{O}+7 \mathrm{O}_{2}=\mathrm{CaO} \bullet \mathrm{Al}_{2} \mathrm{O}_{3} \bullet$

$2 \mathrm{SiO}_{2}+6 \mathrm{CO}_{2}+3 \mathrm{H}_{2} \mathrm{O}$

$\mathrm{CaO}+\mathrm{MgO}+\mathrm{SiO}_{2}+\mathrm{CH}_{4}+2 \mathrm{O}_{2}=\mathrm{CaO} \cdot \mathrm{MgO} \cdot 2 \mathrm{SiO}_{2}$

$+\mathrm{CO}_{2}+2 \mathrm{H}_{2} \mathrm{O}$

$\mathrm{CaO}+\mathrm{MgO}+2 \mathrm{SiO}_{2}+\mathrm{C}_{4} \mathrm{H}_{10}+6,5 \mathrm{O}_{2}=\mathrm{CaO} \bullet \mathrm{MgO} \cdot$

$2 \mathrm{SiO}_{2}+4 \mathrm{CO}_{2}+5 \mathrm{H}_{2} \mathrm{O}$

$\mathrm{CaO}+\mathrm{MgO}+\mathrm{SiO}_{2}+\mathrm{C}_{6} \mathrm{H}_{6}+7,5 \mathrm{O}_{2}=\mathrm{CaO} \cdot \mathrm{MgO} \cdot 2 \mathrm{SiO}_{2}$ $+6 \mathrm{CO}_{2}+3 \mathrm{H}_{2} \mathrm{O}$

$\mathrm{Na}_{2} \mathrm{O}+2 \mathrm{CaO}+3 \mathrm{SiO}_{2}+\mathrm{CH}_{4}+2 \mathrm{O}_{2}=\mathrm{Na} 2 \mathrm{O} \cdot$

$2 \mathrm{CaO} \cdot 3 \mathrm{SiO}_{2}+\mathrm{CO}_{2}+2 \mathrm{H}_{2} \mathrm{O}$

$\mathrm{Na}_{2} \mathrm{O}+2 \mathrm{CaO}+3 \mathrm{SiO}_{2}+\mathrm{C}_{4} \mathrm{H}_{10}+6.5 \mathrm{O}_{2}=\mathrm{Na} 2 \mathrm{O} \cdot$

$2 \mathrm{CaO} \cdot 3 \mathrm{SiO}_{2}+4 \mathrm{CO}_{2}+\mathrm{H}_{2} \mathrm{O}$

$\mathrm{Na}_{2} \mathrm{O}+2 \mathrm{CaO}+3 \mathrm{SiO}_{2}+\mathrm{C}_{6} \mathrm{H}_{6}+7.5 \mathrm{O}_{2}=\mathrm{Na} 2 \mathrm{O}$

$2 \mathrm{CaO} \cdot 3 \mathrm{SiO}_{2}+6 \mathrm{CO}_{2}+3 \mathrm{H}_{2} \mathrm{O}$

Table 5 shows a summary of the reaction of the synthesis of minerals of aluminosilicate sorbents $\left(\Delta \mathrm{G}^{0} \mathrm{~T}\right)$ in the presence of methane, ethane, acetylene, phenol, benzene, and chloromethane. At a temperature of $1500 \mathrm{~K}$, the Gibbs energy of reactions involving methane, ethane, acetylene, phenol, benzene, chloromethane, respectively, is: $-235,-400,-290,-1034,-915,-494$ kJ / mol. 
Table 5 summarizes the synthesis of minerals of aluminosilicate sorbents $\left(\Delta \mathrm{G}^{0} \mathrm{~T}\right)$ in the presence of methane, ethane, acetylene, phenol, benzene, chloromethane. At a temperature of 1500 $\mathrm{K}$, the Gibbs energy of the reactions involving methane, ethane, acetylene, phenol, benzene, chloromethane is, respectively: $-235,-400,-290$, $-1034,-915,-494 \mathrm{~kJ} / \mathrm{mol}$.

Table 5: Temperature influence and hydrocarbon type on $\Delta \mathbf{G}_{\mathrm{T}}^{0}$ formation of claydite minerals

\begin{tabular}{|c|c|c|c|c|c|c|}
\hline \multirow[b]{2}{*}{ T.C. } & \multicolumn{6}{|c|}{$\Delta \mathrm{G}_{\mathrm{T}}^{0}, \mathrm{~kJ} / \mathrm{mol}$ of the mineral } \\
\hline & $\mathrm{CH}_{4}$ & $\mathrm{C}_{2} \mathrm{H}_{6}$ & $\mathrm{C}_{6} \mathrm{H}_{6}$ & $\mathrm{CH}_{3} \mathrm{Cl}$ & $\mathrm{C}_{6} \mathrm{H}_{6} \mathrm{O}$ & $\mathrm{C}_{2} \mathrm{H}_{2}$ \\
\hline \multicolumn{7}{|c|}{ Formation $\mathrm{Al}_{2} \mathrm{O}_{3} \cdot \mathrm{SiO}_{2}$} \\
\hline 298 & $-933,12$ & $-1742,88$ & $-4227,39$ & $-1501,17$ & $-1634,75$ & $-1663,1$ \\
\hline 800 & $-934,02$ & $-1776,25$ & $-6102,58$ & $-1528,37$ & $-2082,5$ & $-2112,6$ \\
\hline 1500 & $-940,0$ & $-1840,2$ & $-8400,3$ & $-1590,76$ & $-2790,10$ & $-2730,2$ \\
\hline \multicolumn{7}{|c|}{ Formation $3 \mathrm{Al}_{2} \mathrm{O}_{3} \bullet \mathrm{SiO}_{2}$} \\
\hline 298 & $-996,6$ & $-1656,53$ & $+575,25$ & $-1403,03$ & $-2995,66$ & $-1578,0$ \\
\hline 800 & $-1004,46$ & $-1708,33$ & $-1246,51$ & -1421 & $-3005,04$ & $-2010,4$ \\
\hline 1500 & $-940,0$ & $-1800,0$ & $-3500,0$ & $-1463,27$ & $-3131,97$ & $-2660,0$ \\
\hline \multicolumn{7}{|c|}{ Formation $\mathrm{CaO} \bullet \mathrm{SiO}_{2}$} \\
\hline 298 & $-866,32$ & $-1675,16$ & $-3244,26$ & $-2293,13$ & $-3018,97$ & $-1291,1$ \\
\hline 800 & $-868,05$ & $-1701,53$ & $-3410,11$ & $-2156,6$ & $-3035,82$ & $-1261,7$ \\
\hline 1500 & $-871,04$ & $-1170,24$ & $-3814,53$ & $-1839,68$ & $-3137,3$ & $-1150,0$ \\
\hline \multicolumn{7}{|c|}{ Formation $\mathrm{CaO} \bullet \mathrm{Al}_{2} \mathrm{O}_{3} \cdot 2 \mathrm{SiO}_{2}$} \\
\hline 298 & $-978,54$ & $-1618,76$ & $-3331,91$ & $-1862,33$ & $-1681,35$ & $-1175,8$ \\
\hline 800 & $-986,21$ & $-1647,48$ & -3348 & $65-1878,4$ & $41-2066,53$ & $3-1142,7$ \\
\hline 1500 & $0-1002,0$ & $-1703,97$ & $-3410,44$ & $-1927,79$ & $-2630,2$ & $-1120,6$ \\
\hline \multicolumn{7}{|c|}{ Formation $\mathrm{CaO} \bullet \mathrm{MgO} \bullet 2 \mathrm{SiO}_{2}$} \\
\hline 298 & $-36,82$ & $-1200,07$ & $-1128,02$ & $+366,64$ & $-1224,6$ & $+581,4$ \\
\hline 800 & $-47,13$ & $-1235,80$ & $-140,17$ & $+328,75$ & $-1256,84$ & $-21,44$ \\
\hline 1500 & $-96,88$ & $-1402,84$ & $-1193,91$ & $+303,77$ & $-1359,51$ & $-561,28$ \\
\hline \multicolumn{7}{|c|}{ Formation $\mathrm{Na}_{2} \mathrm{O}^{\bullet} \mathrm{CaO} 2 \mathrm{SiO}_{2}$} \\
\hline 298 & $-1014,8$ & $-1654,65$ & $-3392,88$ & $-1570,5$ & $-3164,25$ & $-992,16$ \\
\hline 800 & $-1018,77$ & $7-1672,71$ & $-3404,34$ & $-1585,07$ & $-3204,77$ & $-921,68$ \\
\hline 1500 & $0-1021,63$ & $3-1716,64$ & $-3452,37$ & $-1620,92$ & $-3291,87$ & $-921,08$ \\
\hline
\end{tabular}

The analysis of the obtained results showed that the greatest thermodynamic probability is the minerals synthesis in the presence of $\mathrm{C}_{6} \mathrm{H}_{6}$ and the lowest in the presence of $\mathrm{CH}_{4}$. Hydrocarbons in this case (increasing minus) form a series: $\mathrm{CH}_{4}, \mathrm{C}_{2} \mathrm{H}_{6}$, $\mathrm{C}_{2} \mathrm{H}_{2}, \mathrm{C}_{6} \mathrm{H}_{6}$. The greatest thermodynamic probability is characterized by the synthesis of $\mathrm{Al}_{2} \mathrm{O}_{3} \cdot \mathrm{SiO}_{2}$ in the presence of $\mathrm{C}_{6} \mathrm{H}_{6}$, and the lowest is $\mathrm{CaO} \cdot \mathrm{MgO} \cdot 2 \mathrm{SiO}_{2}$ in the presence of $\mathrm{CH}_{4}$. The synthesis of minerals in the presence of $\mathrm{C}_{6} \mathrm{H}_{6}$ is the most thermodynamically probable, and the lowest in the presence of $\mathrm{CH}_{4}$. Hydrocarbons in this case (increasing minus) form a series: $\mathrm{CH}_{4}>\mathrm{C}_{6} \mathrm{H}_{6} \mathrm{O}>\mathrm{C}_{6} \mathrm{H}_{6}$. In the presence of $\mathrm{C}_{6} \mathrm{H}_{6}$ the probability of synthesis decreases in the following series of minerals:
$\mathrm{Al}_{2} \mathrm{O}_{3} \cdot \mathrm{SiO}_{2}>\mathrm{CaO} \cdot \mathrm{SiO}_{2}>3 \mathrm{Al}_{2} \mathrm{O}_{3} \cdot 2 \mathrm{SiO}_{2}>\mathrm{Na} 2 \mathrm{O} \cdot 2 \mathrm{CaO} \cdot$ $2 \mathrm{SiO}_{2}>\mathrm{CaO} \cdot \mathrm{Al}_{2} \mathrm{O}_{3} \cdot 2 \mathrm{SiO}_{2} \cdot \mathrm{CaO} \cdot \mathrm{MgO} \cdot 2 \mathrm{SiO}_{2}$

Based on the calculation, the following conclusions can be drawn:

- $\quad$ The greatest thermodynamic probability is characterized by the synthesis of minerals of adsorbents in the presence of $\mathrm{C}_{6} \mathrm{H}_{6}$, and the lowest - in the presence of $\mathrm{CH}_{4}$.

- In the presence of $\mathrm{C}_{6} \mathrm{H}_{6}$, the synthesis probability decreases in the following series of minerals:

$\mathrm{Al}_{2} \mathrm{O}_{3} \cdot \mathrm{SiO}_{2}>3 \mathrm{CaO} \cdot 2 \mathrm{SiO}_{2}>\mathrm{Na}_{2} \mathrm{O} \cdot \mathrm{CaO} \cdot 3 \mathrm{SiO}_{2}>$ $\mathrm{CaO} \cdot \mathrm{Al}_{2} \mathrm{O}_{3} \cdot 2 \mathrm{SiO}_{2}>\mathrm{CaO} \cdot \mathrm{MgO} \cdot 2 \mathrm{SiO}_{2}$.

- $\quad$ In the presence of the probability of synthesis is reduced in the next series of minerals: In the presence of $\mathrm{CH}_{4}$, the synthesis probability increases in the following series of minerals: $\mathrm{Na}_{2} \mathrm{O} \cdot \mathrm{CaO} \cdot 3 \mathrm{SiO}_{2}>\mathrm{Al}_{2} \mathrm{O}_{3} \cdot \mathrm{SiO}_{2}>3 \mathrm{Al}_{2} \mathrm{O}_{3} \cdot 2 \mathrm{SiO}_{2}$ $>\mathrm{CaO} \bullet \mathrm{MgO} \cdot 2 \mathrm{SiO}_{2}>\mathrm{CaO} \bullet \mathrm{MgO} \cdot 2 \mathrm{SiO}_{2}$.

In the presence of $\mathrm{C}_{6} \mathrm{H}_{6}$ the probability of synthesis increases in the following series of minerals:

$\mathrm{CaO} \cdot \mathrm{MgO} \cdot 2 \mathrm{SiO}_{2}>\mathrm{CaO} \cdot \mathrm{Al}_{2} \mathrm{O}_{3} \cdot \mathrm{SiO}_{2}>\mathrm{Al}_{2} \mathrm{O}_{3} \cdot$ $\mathrm{SiO}_{2}>\mathrm{CaO} \cdot \mathrm{SiO}_{2}>\mathrm{Na}_{2} \mathrm{O} \cdot \mathrm{CaO} \cdot 2 \mathrm{SiO}_{2}$ The greatest thermodynamic probability is characterized by the synthesis of $\mathrm{Al}_{2} \mathrm{O}_{3} \cdot \mathrm{SiO}_{2}$ in the presence of $\mathrm{C}_{2} \mathrm{H}_{2}$, and the lowest is in $\mathrm{CaO} \cdot \mathrm{MgO} \cdot 2 \mathrm{SiO}_{2}$.

It is known from practice that the swelling value is strongly influenced by various exchangeable cations that are present in the composition of clay minerals. These characteristics of clays are mainly due to the presence of the montmorillonite mineral. The cation exchange capacity is explained by the isomorphous replacement of an element with a higher degree of oxidation by an element with a lower oxidation state and this process is activated with different acid activation.

The acid activation of bentonite clay samples was carried out with $0.1 \mathrm{M}$ sulfuric acid, $0.5 \mathrm{M}, 1.8 \mathrm{M}$ sulfuric acid. The results of the chemical analysis showed that the content of acidic components, such as $\mathrm{SiO}_{2} \bullet \mathrm{Al}_{2} \mathrm{O}_{3}$ increases with the increase in the molarity of sulfuric acid. And the content of alkaline and basic oxides, as well as oxides of titanium and iron decreases. These changes are apparently associated with their transition to sulfate solutions, which at flushing, are washed off in the form of sulfate compounds. 
Table 6: Chemical composition of activated and nonactivated bentonite clay

\begin{tabular}{ccccc}
\hline $\begin{array}{c}\text { Component } \\
\text { contents }\end{array}$ & $\begin{array}{c}\text { Non-activated } \\
\text { bentonite clay }\end{array}$ & \multicolumn{3}{c}{$\begin{array}{c}\text { Activated with sulfuric } \\
\text { acid bentonite clay } \\
0,1 \mathrm{M}\end{array}$} \\
& & \multicolumn{4}{c}{$\begin{array}{c}\text { 0,5 } \\
\text { Content }\end{array}$} & $1,8 \mathrm{M}$ \\
& & 50,2 & 51,3 & 52,3 \\
$\mathrm{SiO}_{2}$ & 53,61 & 11,7 & 11,9 & 12 \\
$\mathrm{Al}_{2} \mathrm{O}_{3}$ & 11,22 & 5,6 & 5,3 & 4,8 \\
$\mathrm{Fe}_{2} \mathrm{O}_{3}$ & 5,6 & 1,2 & 1,0 & 0,8 \\
$\mathrm{TiO}_{2}$ & 1,2 & 0,4 & 0,33 & 0,2 \\
$\mathrm{Na}_{2} \mathrm{O}$ & 0,63 & 1,3 & 1,2 & 1,0 \\
$\mathrm{~K}_{2} \mathrm{O}$ & 1,4 & 2,2 & 1,7 & 1,1 \\
$\mathrm{CaO}$ & 2,9 & 0,9 & 0,6 & 0,5 \\
$\mathrm{MgO}$ & 1,0 & & & \\
\hline
\end{tabular}

Acid-activated samples of bentonite clay after flushing were pre-dried to a mass state and were mixed with the addition of oil sludge in an amount of $10-40 \%$. The mixed compounds were granulated and heat treated at temperatures of $700-1000^{\circ} \mathrm{C}$ with isothermal aging for 60 minutes. The results of changes in the physico-mechanical properties of the heat-treated granules at a temperature of $1000^{\circ} \mathrm{C}$ and duration to $60 \mathrm{~min}$ are given in Table 4. The analysis of the obtained data showed that the physico-mechanical characteristics are improved with the addition of oil sludge to the bentonite composition up to $30 \%$. At the same time, the mechanical strength reaches $5.22 \mathrm{MPa}$, the average diameter of the granule is $18.9 \mathrm{~mm}$, the specific surface area is $1560 \mathrm{~cm}^{2} / \mathrm{g}$. The indicators of physico-mechanical characteristics of sorbents based on Lenger clays with an additive up to $40 \%$ do not differ significantly from bentonite clays. However, the specific surface and mechanical strength of sorbents based on bentonite clays with the addition of oil sludge is much higher.

Table 7: Physico - chemical properties of bentonite sorbents after heat treatment

\begin{tabular}{|c|c|c|c|c|}
\hline Sample & $\begin{array}{l}\text { Density, } \\
\mathrm{g} / \mathrm{cm}^{3}\end{array}$ & $\begin{array}{c}\text { Specific } \\
\text { area, } \mathrm{cm}^{2} / \mathrm{g}\end{array}$ & $\begin{array}{c}\text { Effective diameter of } \\
\text { granules, } \mathrm{mm}\end{array}$ & $\begin{array}{l}\text { Strength, } \\
\mathrm{MPa}\end{array}$ \\
\hline Bentonite & 1,94 & 1323 & 15,7 & 4,3 \\
\hline Lenger clay & 2,1 & 1345 & 16,3 & 4,2 \\
\hline Lenger clay with addition $10 \%$ of oil sludge & 2,0 & 1333 & 17,0 & 4,0 \\
\hline Lenger clay with addition $20 \%$ of oil sludge & 2,2 & 1343 & 18,1 & 4,3 \\
\hline Lenger clay with addition $30 \%$ of oil sludge & 2,2 & 1349 & 18,3 & 4,33 \\
\hline Lenger clay with addition $40 \%$ of oil sludge & 2,3 & 1380 & 18,5 & 4,6 \\
\hline Acid activitated bentonite & 2,3 & 1436 & 16,3 & 4,5 \\
\hline Acid activitated bentonite with addition $10 \%$ of oil sludge & 2,4 & 1500 & 18,5 & 5,12 \\
\hline Acid activitated bentonite with addition $20 \%$ of oil sludge & 2,48 & 1530 & 18,6 & 5,2 \\
\hline Acid activitated bentonite with addition $30 \%$ of oil sludge & 2,5 & 1560 & 18,9 & 5,22 \\
\hline Acid activitated bentonite with addition $40 \%$ of oil sludge & 2,5 & 1540 & 18,9 & 5,1 \\
\hline
\end{tabular}

\section{CONCLUSION}

The features of chemical composition of the bentonite clays of Darbaza deposit and refractory clays of Lenger deposit are determined on the basis of physico-chemical analyses.

The composition of oil sludge in which paraffin-naphthenic and aromatic compounds dominate in the organic part and compound of the silicon-aluminum with calcium and iron-containing constituents in the mineral part was determined with mass spectrometric and thermogravimetric analysis.

On the basis of the calculation it follows that the greatest thermodynamic probability is characterized by the sorbent minerals synthesis in the presence of $\mathrm{C}_{6} \mathrm{H}_{6}$ and the lowest in the presence of $\mathrm{CH}_{4}$. Hydrocarbons in this case (increasing in minus form a series: $\mathrm{CH}_{4}>\mathrm{C}_{6} \mathrm{H}_{6} \mathrm{O}>\mathrm{C}_{6} \mathrm{H}_{6}$;

- In the presence of $\mathrm{C}_{6} \mathrm{H}_{6}$ the synthesis probability increases in the following series of minerals: $\mathrm{Al}_{2} \mathrm{O}_{3} \cdot \mathrm{SiO}_{2}>\mathrm{CaO} \cdot \mathrm{SiO}_{2}>3 \mathrm{Al}_{2} \mathrm{O}_{3}$ $\cdot 2 \mathrm{SiO}_{2}>\mathrm{Na}_{2} \mathrm{O} \cdot \mathrm{CaO} \cdot 3 \mathrm{SiO}_{2}>\mathrm{CaO} \cdot \mathrm{Al}_{2} \mathrm{O}_{3} \cdot \mathrm{SiO}_{2}$.

- $\quad$ The greatest thermodynamic probability is characterized by the synthesis of $\mathrm{Al}_{2} \mathrm{O}_{3} \cdot \mathrm{SiO}_{2}$ in the presence $\mathrm{C}_{6} \mathrm{H}_{6}$.

The physico-mechanical properties of activated bentonite clays with the addition of oil sludge $10-30 \%$ are much higher than those indexes of the refractory clays of Lenger deposit. 


\section{ACKNOWLEDGMENT}

This research did not receive any specific grant from funding agencies in the public, commercial, or not-for-profit sectors.

\section{REFERENCE}

1. Su, Ch.; Duan, L.; Donat, F.; Anthony, E. J., Appl Energy., 2018, 210, 117-126.

2. Tleuov A. S.; Tleuova S.T.; Arystanova S.D., Altybayev Zh.M.; Suigenbayeva A. Zh. Orient. J. Chem. Coden: ojcheg., 2016, 32(5), 2577-2584.

3. Soni.; V. K.; Sharma; P. R.; Choudhary, G.; Pandey, S.; Sharma, R. K.; ACS Sustainable Chem. Eng., 2017, 5(6), 5351-5359.

4. Cordell, D.; Rosemarin, A.; Schröder, J. J.; Smit, A. L.; Chemosphere., 2011, 84, 747-758.

5. Tleuova S. T.; Tleuova S.T.; Arystanova S.D.; Bolysbek A. A.; Baiysbay O.P.; Abzhanova A. S. Orient. J. Chem. Coden: ojcheg., 2018,
34(3), 231-5039. 12c.

6. Cieslik, B.; Konieczka, P.; Journal of Cleaner Production., 2017, 142(4), 1728-1740.

7. Tleuov A. S.; Altybayev Zh. M.; Tleuova S.T.; Sagat M.; Shapalov Sh. Reports of the National Academy of science of RK., 2016, 89-95, 10.

8. L. Bandura.; A,Woszuk.; D. Kołody. ;W. Franus, Minerals., 2017, 7, 37.

9. S Pandey-Journal of Molecular Liquids, Elsevier., 2017.

10. Herzel, H.; Krüger, O.; Hermann, L.; Adam, C., Science of The Total Environment., 2016, 542( B), 1136-1143. 